\title{
In Situ Bioremediation through Mulching of Soil Polluted by a pÿCopper Nickel Smelter
}

\section{Kiikkilä, $\mathrm{O}$.}

American Society of Agronomy, Crop Science Society of America, and Soil Science Society of America.

2001

Kiikkilä, O. et al. 2001. In Situ Bioremediation through Mulching of Soil Polluted by a pÿCopper Nickel Smelter. Journal of Environmental Quality 30(4): 1134-1143.

http://hdl.handle.net/1975/268

Downloaded from Helda, University of Helsinki institutional repository.

This is an electronic reprint of the original article.

This reprint may differ from the original in pagination and typographic detail.

Please cite the original version. 


\title{
In Situ Bioremediation through Mulching of Soil Polluted by a Copper-Nickel Smelter
}

\author{
Oili Kiikkilä,* Jonna Perkiömäki, Matthew Barnette, John Derome, Taina Pennanen,
} Esa Tulisalo, and Hannu Fritze

\begin{abstract}
Bioremediation of a heavy metal-polluted soil was investigated in a 3-yr field experiment by adding mulch to a polluted forest floor. The mulch consisted of a mixture of compost and woodchips. The remediation treatment decreased the toxicity of the soil solution to bacteria as determined by the $\left[{ }^{3} \mathrm{H}\right]$-thymidine incorporation technique, that is, by measuring the growth rate of soil bacteria extracted from unpolluted humus after exposing them to soil solution containing heavy metals from the experimental plots. Canonical correlation analysis was performed in order to identify the chemical and microbiological changes in the soil. The $\mathrm{pH}$ of the mulched organic layer increased by one unit. The concentration of complexed $\mathrm{Cu}$ increased and that of free $\mathrm{Cu}^{2+}$ decreased in the soil solution from the mulch treatment. According to basal respiration and litter decomposition, microbial activity increased during the $3 \mathrm{yr}$ following the remediation treatment. The $\left[{ }^{3} \mathbf{H}\right]$-thymidine incorporation technique was also used to study the growth rate and tolerance of bacteria to $\mathrm{Cu}$. The bacterial growth rate increased and the $\mathrm{Cu}$ tolerance decreased on the treated plots. The structure of the microbial community, as determined by phospholipid fatty acid (PLFA) analysis, remained unchanged. The results indicate that remediation of the polluted soil had occurred, and that adding a mulch to the forest floor is a suitable method for remediating heavy metal-polluted soil.
\end{abstract}

$\mathrm{U}$ NLIKE organic pollutants, metals cannot be degraded into a harmless form such as carbon dioxide, but persist indefinitely in the environment. The only approaches available for remediating heavy metalpolluted soils are to remove the metals or to convert the metals into less bioavailable forms. Both approaches are employed in phytoremediation, that is, the use of pollutant-accumulating plants to remove metals from soil, or the use of plants to reduce the bioavailability of heavy metals (Salt et al., 1998). The immobilization of heavy metals by a wide range of binding agents has been tested in laboratory conditions. Cation exchange resins, limestone, clays, ferrous sulfate (Czupyrna et al., 1989), minerals (Chen et al., 1997; García-Sánchez et al., 1999), synthetic zeolites (Czupyrna et al., 1989; Gworek, 1992), hydrous manganese oxide, steel shots and beringite (a modified aluminosilicate) (Mench et al., 1994), and biomass residues (Fisher et al., 1998) have been suggested for the in situ remediation of heavy metal-polluted soil. In field experiments, limestone

Oili Kiikkilä, Jonna Perkiömäki, Matthew Barnette, Taina Pennanen, and Hannu Fritze, Vantaa Research Center, Finnish Forest Research Institute, P.O. Box 18, FIN-01301 Vantaa, Finland. John Derome, Rovaniemi Research Station, Finnish Forest Research Institute, P.O Box 16, FIN-96301 Rovaniemi, Finland. Esa Tulisalo, Dep. of Limnology and Environmental Protection, P.O. Box 62, FIN-00014 Univ. of Helsinki, Finland. Received 8 Sept. 2000. *Corresponding author (Oili.Kiikkila@metla.fi).

Published in J. Environ. Qual. 30:1134-1143 (2001).
(Mälkönen et al., 1999), gravel sludge (Krebs et al., 1999), sewage sludge and fly ash (Kelly and Tate, 1998), beringite and compost (Vangronsveld et al., 1995a,b; Vangronsveld et al., 1996), and Fe-rich limed compost (Li et al., 2000) have been found to immobilize metals. Because one chemical extraction method is often inadequate to measure the degree of immobilization of all the components (Vangronsveld and Clijsters, 1992), we also fractioned $\mathrm{Cu}$ in the soil solution into $\mathrm{Cu}^{2+}$ and complexed $\mathrm{Cu}$.

In order to assess the success of remediation, some bioassays are also needed. Immobilization has resulted in an increase in tree growth (Mälkönen et al., 1999), a decrease in heavy metal concentrations in plants (Krebs et al., 1999), a reduction in soil phytotoxicity, and successful revegetation (Li et al., 2000; Vangronsveld et al., 1995b). The recovery of nutrient cycling mediated by soil microbes is often of major importance in heavy metal-polluted sites. An increase in microbial activity (Mälkönen et al., 1999; Kelly and Tate, 1998) and establishment of a mycorrhizal network (Vangronsveld et al., 1996) have been reported. More information is needed concerning the effects of remediation on soil microbiota. To our knowledge this has not been studied using methods describing microbial activities and biomass, bacterial $\mathrm{Cu}$ tolerance, and structure of the microbial community.

Compost is considered to be a good amendment agent for bioremediating heavy metal-polluted soil (Vangronsveld and Clijsters, 1992; Li et al., 2000). Unfortunately, very little information has been published about the effects of compost amendments on the stabilization of heavy metal-contaminated soils. Sewage sludge has been used successfully in remediating mine spoils, and a good review of these studies is presented in Sabey et al. (1990). A mixture of compost and lime (Li et al., 2000) or modified aluminosilicate (Vangronsveld et al., 1996) was mixed with soil that was heavily polluted with $\mathrm{Zn}$ and $\mathrm{Cd}$ especially. Copper is the main pollutant at the study site where we mulched the forest floor with a mixture of compost and woodchips, an easily available and inexpensive waste material. Addition of mature compost to soil is known to enhance soil fertility by

\footnotetext{
Abbreviations: AO, number of bacterial cells; BIOL, canonical biolog ical variable; CCA, canonical correlation analysis; CHEM, canonical chemical variable; $\mathrm{Cu}_{\text {comp }}$, complexed copper in soil solution; $\mathrm{Cu}_{\mathrm{exc}}$, exchangeable copper concentration in soil; DM, dry matter weight; $\mathrm{IC}_{50}$, inhibition concentration (i.e., bacterial copper tolerance); MDS, multidimensional scaling; $\mathrm{Ni}_{\mathrm{exc}}$, exchangeable nickel concentration in soil; OM, organic matter weight; PLFA, phospholipid fatty acid; PLFA $_{\text {bact }}$, an indicator of bacterial biomass; PLFA fung, an indicator of fungal biomass; $\mathrm{T}$, treated; TdR, $\left[{ }^{3} \mathrm{H}\right]$-thymidine incorporation rate (i.e., bacterial growth rate); $\mathrm{TdR} / \mathrm{AO}$, specific bacterial growth rate, $\mathrm{U}$, untreated.
} 
modifying the chemical, physical, and biological properties of the soil. A comprehensive review of this subject is presented in Dick and McCoy (1993). Compost increases the water-holding capacity of the soil, the soil $\mathrm{pH}$, and microbial activity. The organic matter in compost also complexes metals into less bioavailable forms (Vangronsveld and Clijsters, 1992). Copper especially is known to form stable complexes with organic matter (Baker and Senft, 1995). Compost also introduces new active microbiota and provides a nutrient source for the microorganisms. We added woodchips to the compost in order to increase the amount of slow-release carbon. Mulching a polluted forest floor with a layer of organic material has several advantages in the remediation of heavy metal-polluted soil, since it prevents drying and erosion of the soil and thus promotes revegetation.

We aimed to decrease the bioavailable fractions of heavy metals in the soil by mulching the forest floor with a mixture of compost and woodchips. The subsequent increase in soil $\mathrm{pH}$ would precipitate heavy metals, and the organic matter addition would increase heavy metal complexation. Our hypothesis was that bioremediation of the soil would result in (i) an increase in microbial activities, (ii) a decrease in bacterial heavy metal tolerance, and (iii) a change in the structure of the microbial community. This study on soil bioremediation is the microbial part of the "Recovery of a Boreal Forest Ecosystem from Long-Term Heavy-Metal Pollution" research project.

\section{MATERIAL AND METHODS}

\section{Study Site}

The bioremediation experiment was established at a distance of $0.5 \mathrm{~km}$ from a Cu-Ni smelter in southwestern Finland $\left(61^{\circ} 19^{\prime} \mathrm{N}, 22^{\circ} 9^{\prime} \mathrm{E}\right)$. The study site was of the relatively infertile Calluna forest site type (Cajander, 1949), with a tree cover consisting of Scots pine (Pinus sylvestris L.). The ground vegetation on the study sites has almost completely disappeared (Salemaa et al., 2001), and the growth of trees is extremely poor (Mälkönen et al., 1999).

The experiment was established on an esker, the soil consisting of sorted fine or fine/coarse sand with no stones. The soil was classified as an orthic Podzol (Anonymous, 1988). The original humus layer over the podzolized mineral soil was relatively thin $(0-3 \mathrm{~cm})$ mor $\left(\mathrm{A}_{\mathrm{O} 1} / \mathrm{A}_{\mathrm{O} 2} ; \mathrm{F} / \mathrm{H}\right)$ with a clearly pronounced, dry, undecomposed litter layer. The structure of the humus layer $\left(\mathrm{A}_{\mathrm{O} 1} / \mathrm{A}_{\mathrm{O} 2} ; \mathrm{F} / \mathrm{H}\right)$ has changed, and has an extremely low amount of fine-root biomass (Helmisaari et al., 1999), high heavy metal concentrations (Derome and Lindroos, 1998), and an average organic matter content of $400 \mathrm{~g}$ $\mathrm{kg}^{-1}$. In this and earlier publications it is therefore called the organic layer. Derome and Lindroos (1998) reported a clear increasing gradient in many heavy metal concentrations in the organic layer with decreasing distance to the smelter. Total concentrations of $\mathrm{Cu}, \mathrm{Ni}, \mathrm{Fe}, \mathrm{Zn}, \mathrm{Cd}, \mathrm{Pb}$, and $\mathrm{Cr}$ were 6000 , $460,18600,520,5.0,310$, and $31 \mathrm{mg} \mathrm{kg}^{-1}$, respectively. According to Derome and Nieminen (1998), there is also a severe shortage of $\mathrm{Ca}, \mathrm{Mg}$, and $\mathrm{K}$ in a plant-available form, the exchangeable concentrations being 580, 40, and $132 \mathrm{mg} \mathrm{kg}^{-1}$, with reduced concentrations of these nutrients in the Scots pine needles. However, the accumulation of heavy metals and sulfur has not had any effects on soil acidity, that is, on $\mathrm{pH}$ or on exchangeable acidity in the organic layer and uppermost mineral soil layer (Derome and Lindroos, 1998).

More than $50 \mathrm{yr}$ of heavy metal accumulation in the soil has had direct toxic effects on the soil microbiota. The overall microbiological activity has decreased drastically (Fritze et al., 1989), the structure of the microbial community has changed, and the bacterial community is highly resistant to heavy metals (Pennanen et al., 1996; Fritze et al., 1997). This is reflected in a decreased rate of litter decomposition.

\section{Experimental Design}

In summer 1996 we marked out 36 sample plots at the site. Each sample plot was $5 \times 5 \mathrm{~m}$, including a 1-m-wide buffer zone. Eighteen of the plots were covered with a 5-cm-thick layer of mulch (treated $=\mathrm{T}$ ), and the other 18 plots were left untreated (untreated $=U$ ). The mulch was spread directly over the layer of undecomposed plant litter on the forest floor. The mulch consisted of a mixture of compost and woodchips (1:1, volume). The compost was 14 mo old and had been produced in outdoor windrows from a mixture of organic household waste and coarse woodchips (diam. ca. $5 \mathrm{~cm}$ ) at the Ämmässuo Waste Handling Centre (Espoo, Finland). According to Mäkelä-Kurtto and Sippola $(1995,1996)$, the average nutrient concentrations (per dry matter) of compost that is sold as a garden soil amendment and produced at the same waste handling centre are: $\mathrm{NH}_{4}-\mathrm{N}, 370 \mathrm{mg} ; \mathrm{NO}_{3}-\mathrm{N}, 760 \mathrm{mg}$; $\mathrm{Ca}, 28 \mathrm{~g} ; \mathrm{K}, 16 \mathrm{~g} ; \mathrm{Mg}, 3 \mathrm{~g} ; \mathrm{P}, 2 \mathrm{~g} ; \mathrm{Fe}, 7 \mathrm{~g} ; \mathrm{Al}, 800 \mathrm{mg} ; \mathrm{Mn}$, 300 mg; Cu, 60 mg; Zn, 250 mg; Ni, 3 mg; Cd, 0.6 mg; Pb, 51 $\mathrm{mg}$; and $\mathrm{Cr}, 2.6 \mathrm{mg} \mathrm{kg}^{-1}$. According to our own measurements, the $\mathrm{pH}$ of the compost was 7.7 , total organic C content $280 \mathrm{~g}$ $\mathrm{kg}^{-1}$, and total $\mathrm{N}$ content $26 \mathrm{~g} \mathrm{~kg}^{-1}$, giving a $\mathrm{C}$ to $\mathrm{N}$ ratio of 11. The $\mathrm{C}$ to $\mathrm{N}$ ratio is used as a measure of compost maturity; in mature compost the ratio is between 10 and 12 (Chefetz et al., 1996). The mulch was prepared 1 wk before spreading by mixing the compost with woodchips (diam. $<20 \mathrm{~mm}$ ) of Scots pine and Norway spruce [Picea abies (L.) Karst.] stemwood. The carbon content of stemwood is ca. $500 \mathrm{~g} \mathrm{~kg}^{-1} \mathrm{C}$, but the contents of $\mathrm{N}$ and other nutrients are insignificant in this context. The mulch contained $320 \mathrm{~g} \mathrm{C}$ and $20 \mathrm{~g} \mathrm{~N} \mathrm{~kg}^{-1}$ dry matter, giving a $\mathrm{C}$ to $\mathrm{N}$ ratio of 16 , and $\mathrm{pH}$ 6.3. Compost (excluding the woodchips) was added to the plots at a dose of $5.4 \mathrm{~kg} \mathrm{~m}^{-2}$ (dry matter weight).

Soil samples were taken from the 0 - to $3-\mathrm{cm}$ organic layer below the polluted litter layer on each plot. One composite sample (five replicates) was taken from each plot using a spoon (area $10 \mathrm{~cm}^{2}$ ) after the litter layer (U plots) or the mulch and the litter layer ( $\mathrm{T}$ plots) had been removed. Care was taken to ensure that the $\mathrm{T}$ samples did not contain any mulch. The samples were taken to the laboratory within 1 or $2 \mathrm{~d}$ after sampling. The fresh samples were sieved (mesh size $28 \mathrm{~mm}$ ) and stored for $1 \mathrm{~d}$ at room temperature in order to stabilize the microbiota, and then stored at $4^{\circ} \mathrm{C}$ until analysis. The samples for phospholipid fatty acid (PLFA) analysis were frozen immediately, and those for exchangeable metal analyses were air-dried. Soil samples were collected in autumn 1996 , spring 1997, autumn 1997, spring 1998, and autumn 1998.

\section{Chemical Analyses}

Total $\mathrm{C}$ and $\mathrm{N}$ in the mulch were determined by dry combustion (LECO [St. Joseph, MI] CHN-600). Dry matter weight (DM) was determined by drying overnight in an oven at $105^{\circ} \mathrm{C}$, and the organic matter content (OM) as loss in weight on ignition $\left(550^{\circ} \mathrm{C}\right)$. The $\mathrm{pH}$ was measured from a fresh soil-water suspension (1:3, volume). Exchangeable copper $\left(\mathrm{Cu}_{\text {exc }}\right)$ and nickel $\left(\mathrm{Ni}_{\text {exc }}\right)$ were determined by extracting $2 \mathrm{~g}$ of air-dried 
soil with $100 \mathrm{~mL}$ of $0.1 \mathrm{MBaCl}_{2}$ on a shaker for $1 \mathrm{~h}$. The extract was filtered and the $\mathrm{Cu}$ and $\mathrm{Ni}$ concentrations determined by atomic absorption spectrometry (AAS).

Copper fractionation into free $\mathrm{Cu}^{2+}$ ions and complexed $\mathrm{Cu}\left(\mathrm{Cu}_{\text {comp }}\right)$ was carried out on the soil solution extracted from samples taken at the last sampling round. Soil solution was obtained from the fresh soil samples by centrifugation for 40 min at $30100 \times g$ on a Beckman (Fullerton, CA) centrifuge $(\mathrm{J} 2-21 \mathrm{M} / \mathrm{E})$ with a fixed angle rotor $(\mathrm{JA}-14)$ at $5^{\circ} \mathrm{C}$. The samples were placed in special two-part, nylon centrifuge tubes (Geisler, 1996). After centrifugation, the soil solution was removed from the bottom section of the centrifuge tube, and then diluted to $50 \mathrm{~mL}$ for $\mathrm{Cu}$ fractionation. Fractionation into $\mathrm{Cu}^{2+}$ and $\mathrm{Cu}_{\text {comp }}$ was performed by passing the diluted soil solution sample through a cation exchange column (Amberlite 120 Plus, $\mathrm{Na}^{+}$form; ICN Biomedicals, Costa Mesa, CA) (Berggren, 1989). The $\mathrm{Cu}$ concentration in the sample was determined before and after passage through the column by atomic absorption spectrometry. The $\mathrm{Cu}$ concentration in the effluent was considered to be $\mathrm{Cu}_{\text {comp }}$ (neutral or negatively charged species), and the difference between the $\mathrm{Cu}$ concentration before and after passage through the column was considered to be the concentration of $\mathrm{Cu}^{2+}$ ions.

\section{Toxicity Test}

The toxicity of the soil solution (prepared as described above) to bacteria was studied on samples taken at the last sampling round by the $\left[{ }^{3} \mathrm{H}\right]$-thymidine incorporation technique in order to measure the bacterial growth rates. The $\left[{ }^{3} \mathrm{H}\right]-$ thymidine incorporation rate was determined as described by Bååth (1992a,b) and modified by Kiikkilä et al. (2000). We used bacteria extracted from an unpolluted forest site (Fritze et al., 2000). Soil solution $(0.2 \mathrm{~mL})$ from the plots was added to $1.8 \mathrm{~mL}$ of bacterial suspension, and the $\left[{ }^{3} \mathrm{H}\right]$-thymidine incorporation procedure was then performed as described below. It was expected that the more toxic the soil solution, the less $\left[{ }^{3} \mathrm{H}\right]$-thymidine would be incorporated.

\section{Microbial Activities}

Microbial activity was measured as basal respiration (BR). The $\mathrm{CO}_{2}$ evolved in $24 \mathrm{~h}$ was determined by gas chromatography as described by Pietikäinen and Fritze (1995). Litter decomposition was studied with litter bags (nylon net bag, $7 \times$ $7 \mathrm{~cm}$, of 1-mm pore size), containing green Scots pine needles (1 g DM) collected from an unpolluted area. The litterbags (20 on each sample plot) were inserted immediately under the polluted litter layer. The bags on the T plots were covered by the litter layer and the mulch. The bags were removed after three growing seasons, dried, washed, and weighed. The litter weight lost was calculated.

Bacterial growth rate and copper tolerance were determined by the $\left[{ }^{3} \mathrm{H}\right]$-thymidine incorporation technique. Soil equivalent to $1.3 \mathrm{~g}$ of organic matter was shaken in $100 \mathrm{~mL}$ of distilled water for $1 \mathrm{~h}$ at $250 \mathrm{rpm}$ at $4^{\circ} \mathrm{C}$. The soil suspension was centrifuged for $10 \mathrm{~min}(750 \times g)$. The supernatant (i.e., the bacterial suspension) was then incubated at $22^{\circ} \mathrm{C}$ for $2 \mathrm{~h}$ with $\left[{ }^{3} \mathrm{H}\right]$-labelled thymidine. The growing bacteria incorporate $\left[{ }^{3} \mathrm{H}\right]$-thymidine, and the incorporation rate (TdR) was measured by counting the radioactivity in a Wallac (Turku, Finland) 1411 liquid scintillation counter using the fine-tuned external standard method (Anonymous, 1991). In the copper tolerance assay the bacterial suspension was mixed with a solution containing $0,0.0001,0.001,0.01$, and $0.1 \mathrm{M} \mathrm{Cu}$. Growth inhibition $\left(\mathrm{IC}_{50}\right)$ was calculated as the $\log \mathrm{Cu}$ concentration $(M)$ giving a $50 \%$ reduction in $\left[{ }^{3} \mathrm{H}\right]$-thymidine incorpo- ration. The lower the absolute $\mathrm{IC}_{50}$ value, the greater is the tolerance of the bacterial community. The isotope dilution procedure, as described by Pollard and Moriarty (1984), was performed on four replicate samples of both treatments taken at the last sampling round. Since the degree of participation was ca. $33 \%$ for both treatments ( $U$ and $T$ ), dilution of the isotope was not taken into account in the calculations. The supernatant used for determining the bacterial growth rate was also used to determine the number of bacterial cells in the sample. The diluted soil suspension was filtered through a black 0.2- $\mu \mathrm{m}$ Poretics polycarbonate membrane (Osmonics, Minnetonka, MN) and the cells were stained with acridine orange. The number of cells (AO) was counted under a Leitz Laborlux S epifluorescence microscope (Ernst Leitz, Wetzlar, Germany). The specific $\left[{ }^{3} \mathrm{H}\right]$-thymidine incorporation depicting the growth rate of the bacterial cells (TdR/AO) was calculated.

\section{Structure of the Microbial Community}

The microbial community structure was analyzed as described by Frostegård et al. (1993a) and Pennanen et al. (1999) by extracting the microbial-derived phospholipid fatty acids (PLFAs) from the organic soil sample. Different subsets of the microbial community have different PLFA patterns in their cell membrane, and a treatment-induced change in the PLFA pattern is an indication of a changed microbial community. To briefly summarize this procedure, $0.5 \mathrm{~g}$ fresh weight of organic soil was extracted with chloroform-methanol-citrate buffer mixture (1:2:0.8) and the lipids separated into neutral lipids, glycolipids, and phospholipids on a silicic acid column. The phospholipids were subjected to a mild alkaline methanolysis, and the fatty acid methyl esters were analyzed by gas chromatography (flame ionization detector) using a 50-m HP-5 (phenylmethyl silicone) capillary column (Hewlett-Packard, Palo Alto, CA). Helium was used as a carrier gas. The temperatures of the injector and detector were 230 and $270^{\circ} \mathrm{C}$, respectively. The initial temperature of the oven was $50^{\circ} \mathrm{C}$ and it was raised at the rate of $30^{\circ} \mathrm{C} \mathrm{m^{-1 }}$ to $160^{\circ} \mathrm{C}$, then at the rate of $2^{\circ} \mathrm{C} \mathrm{min}{ }^{-1}$ to $270^{\circ} \mathrm{C}$, after which the oven was kept for $5 \mathrm{~min}$ at the final temperature of $270^{\circ} \mathrm{C}$. Peak areas were quantified by adding methyl nonadecanoate fatty acid (19:0) as an internal standard.

Fatty acids are designated in terms of the ratio between the total number of carbon atoms and the number of double bonds, followed by the position of the double bond with respect to the methyl end of the molecule. The prefixes $i$ and a indicate iso- and anteiso branching, br indicates unknown branching, and cy indicates a cyclopropane fatty acid. Me refers to the position of the methyl group with respect to the carboxyl end of the chain. The prefix $\mathrm{C}(\mathrm{C} 15: 1)$ indicates that the PLFA has 15 carbon atoms and one double bond, but the arrangement of the carbon atoms (e.g., branching position) was not confirmed. The individual PLFAs were expressed as percentage of the total amount of PLFAs detected in a soil sample $(\mathrm{mol} \%)$. The total sum of PLFAs was used as an indicator of microbial biomass $\left(\mathrm{PLFA}_{\text {tot }}\right)$. The sum of PLFAs considered to be predominantly of bacterial origin (i15:0,

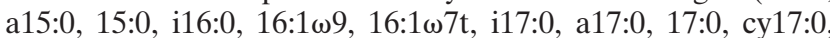
$18: 1 \omega 7$, and cy19:0) was chosen as an index of the bacterial biomass $\left(\right.$ PLFA $\left._{\text {bact }}\right)$ (Frostegård and Bååth, 1996). The amount of PLFA 18:2 $\omega 6,9$ was used as an indicator of the fungal biomass (PLFA fung $_{\text {f }}$ ) because it is suggested to be mainly of fungal origin in the soil (Federle, 1986) and it is known to correlate with the amount of ergosterol (Frostegård and Bååth, 1996), a sterol found only in fungi. The ratio between 


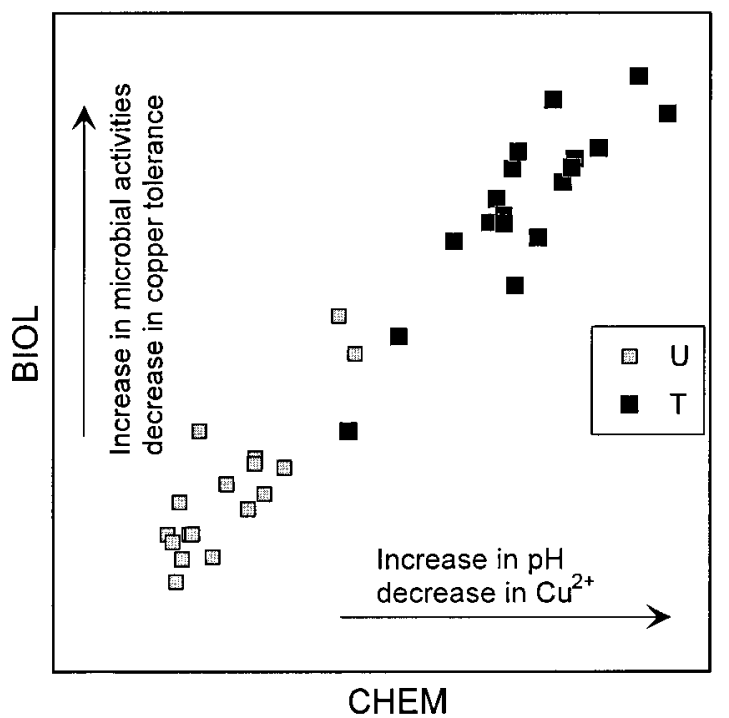

Fig. 1. Plot of the untreated (U) and the treated (T) sample plots of the last sampling date on the first canonical variables, CHEM (the chemical data set) and BIOL (the biological data set) from canonical correlation analysis. The arrows indicate the influence of the most important variables on formation of the canonical variables.

fungal and bacterial PLFAs was used as an index of the fungal/ bacterial (PLFA fung $/$ PLFA $_{\text {bact }}$ ) biomass in the soil.

\section{Statistical Analyses}

The results are calculated per organic matter content (OM). Canonical correlation analysis (CCA), performed for each sampling date separately, was used to investigate the relationships between chemical and biological variables. It generates pairs of linear combinations from two sets of original variables such that the correlation is maximal between the pairs of the new canonical variables (Gittins, 1985). A canonical variable is a linear summary of the set of input variables (Gittins, 1985). The chemical dataset consisted of $\mathrm{pH}, \mathrm{Cu}_{\mathrm{exc}}, \mathrm{Cu}^{2+}, \mathrm{Ni}_{\mathrm{exc}}, \mathrm{DM}$, $\mathrm{OM}$, and the biological dataset of basal respiration (BR), TdR, mass loss of litter (ML), AO, IC I0 $_{0}, \mathrm{TdR} / \mathrm{AO}, \mathrm{PLFA}_{\text {tot }}, \mathrm{PLFA}_{\text {bact }}$, PLFA $_{\text {fung, }}$, and PLFA bact $/$ PLFA $_{\text {fung }}$, depending on which variables were determined on the sampling in question. The new canonical variables are called CHEM and BIOL. Graphical presentations of CCA are scatter plot diagrams of the sample plots on CHEM ( $x$ axis) and BIOL ( $y$ axis) (Fig. 1). Canonical structure (i.e., correlations between the original variables and canonical variables) was applied to the figure with the arrows of the original variables indicating the influence of the most important original variables on formation of the new canonical variable. Redundancy analysis, which can be seen as a part of the CCA, was used to determine the proportion of the variation that the canonical variables explain either in their own or the alternate data set (Van den Wollenberg, 1977).

Prior to the CCA the relationships between individual variables were examined by plotting the variables against each other. $\mathrm{Log}$ transformations were made for $\mathrm{Cu}^{2+}$ and $\mathrm{Cu}_{\text {exc }}$ variables in order to make the relationships between the variables linear. Canonical correlation analyses were performed on SAS using the CANCORR procedure (SAS Institute, 1996).

To examine the statistical difference between the treatments, one-way analysis of variance (ANOVA) was performed for

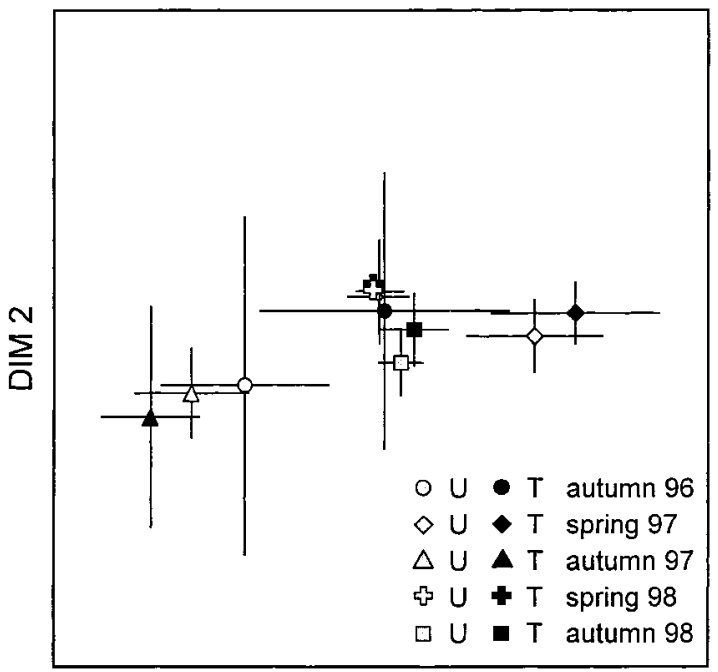

DIM 1

Fig. 2. Nonmetric multidimensional scaling (MDS) ordination of the sample plots with respect to sampling date and treatments. Symbols indicate the mean of 18 replicate untreated (U) and treated (T) plots, and bars indicate the standard deviation of the replicates.

the canonical variables CHEM and BIOL (Fig. 1) and for the variables measured in the soil solution (Table 2).

The PLFA pattern was explored with global nonmetric multidimensional scaling (MDS), using the program package PC-ORD (McCune and Mefford, 1999), which considers the rank order of distances (Minchin, 1987). Five repeated samplings resulted in 180 sample units and 31 PLFAs. The principle on which MDS operates is to find a representation of the data in a few dimensions, the distances in the ordination of the sample plots reflecting the (dis)similarities between the respective PLFA patterns as closely as possible. The pairwise dissimilarities were computed using a Bray-Curtis coefficient, which is widely used in community-level studies (Clarke, 1999), and has been found to be a robust measure of quantitative dissimilarity (Faith et al., 1987). Graphical presentation of MDS is in the form of scatter plot diagrams (Fig. 2 and 3 ) about the sample plots. The final ordination diagram is

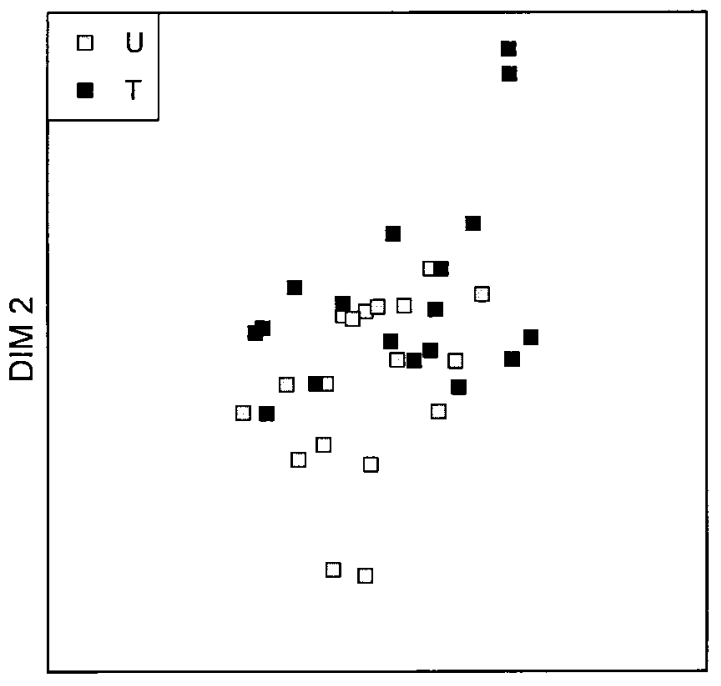

DIM 1

Fig. 3. Plot of the untreated (U) and the treated (T) sample plots of the last sampling date in autumn 1998 from multidimensional scaling (MDS) ordination in Fig. 2. 


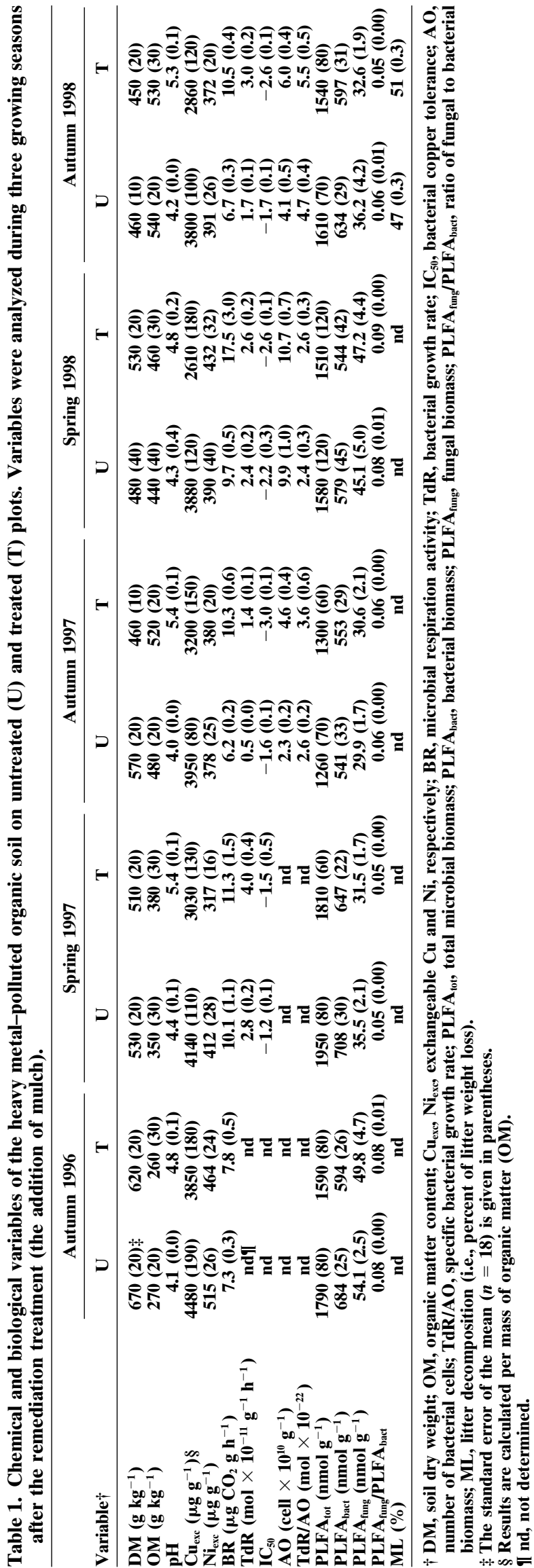

interpreted as follows: the closer the two sample plots are on the ordination, the more similar is their PLFA pattern. The vector fitting procedure was performed with the PC-ORD program in order to study the correlation between the ordination and the environmental variables that could possibly separate the treatments or the sampling dates $\left(\mathrm{pH}, \mathrm{Cu}_{\mathrm{exc}}, \mathrm{DM}, \mathrm{OM}\right)$.

Prior to MDS, the mole percentages of the PLFA values were double-square root transformed $\left(y^{0.25}\right)$ to down-weight the influence of very abundant PLFAs. The single missing PLFA values (45) were replaced by the mean of each sampling date. A total of 18 outlier samples, of which 16 were from the third sampling, were excluded. PC-ORD autopilot mode with medium thoroughness was used to compute the ordination.

\section{RESULTS}

\section{Chemical Analyses}

During the first summer, application of the mulch increased the $\mathrm{pH}$ of the organic layer in $17 \mathrm{wk}$ from 4.1 to 4.8 (Table 1 ). In the following spring the $\mathrm{pH}$ was 4.4 on the untreated $(\mathrm{U})$ and 5.4 on the treated $(\mathrm{T})$ plots. The $\mathrm{Ni}_{\text {exc }}$ concentration in the organic layer did not vary systematically between the treatments. The $\mathrm{Cu}_{\text {exc }}$ concentration was lower on the $\mathrm{T}$ plots from the first sampling onward, the $\mathrm{Cu}_{\mathrm{exc}}$ concentration on the last sampling being $2860 \pm 120$ and $3800 \pm 100 \mu \mathrm{g} \mathrm{g}^{-1}$ for the $\mathrm{T}$ and $\mathrm{U}$ plots, respectively. The $\mathrm{Cu}^{2+}$ concentration in the soil solution was clearly lower $(p<0.001)$ on the $\mathrm{T}$ plots $\left(1.6 \pm 0.2 \mathrm{mg} \mathrm{L}^{-1}\right)$ than on the U plots $(9.1 \pm$ $0.9 \mathrm{mg} \mathrm{L}^{-1}$ ) on the last sampling (Table 2). At the same time, the proportion of $\mathrm{Cu}_{\text {comp }}$ out of total $\mathrm{Cu}$ and the concentration of DOC in the soil solution were higher $(p<0.001)$ on the $\mathrm{T}$ plots than on the $\mathrm{U}$ plots. The values for the $\mathrm{T}$ and $\mathrm{U}$ plots for $\mathrm{Cu}_{\text {comp }} / \mathrm{Cu}_{\text {tot }}$ were $0.41 \pm$ 0.04 and $0.04 \pm 0.01$, and for DOC $134 \pm 8$ and $76 \pm$ $4 \mathrm{mg} \mathrm{L}^{-1}$, respectively.

\section{Toxicity Test}

The toxicity of the soil solution to bacteria on the T plots $3 \mathrm{yr}$ after application of the mulch was lower $(p<$ $0.001)$ than that on the U plots. When the soil solution from the $\mathrm{T}$ plots was added to a bacterial suspension extracted from unpolluted humus the bacterial growth rate was higher than that with the soil solution from the U plots. The $\left[{ }^{3} \mathrm{H}\right]$-thymidine incorporation for the $\mathrm{T}$ and U plots was 2.3 and $1.4 \pm 0.1 \times 10^{-11} \mathrm{~mol}\left[{ }^{3} \mathrm{H}\right]$-thymidine $\mathrm{g}^{-1} \mathrm{~h}^{-1}$, respectively (Table 2). There was strong correlation between $\left[{ }^{3} \mathrm{H}\right]$-thymidine incorporation and the $\mathrm{Cu}^{2+}$ concentration in the soil solution (Pearson; $r=-0.72$ ).

Table 2. Results of the soil solution of organic soil from the experimental plots in autumn 1998.

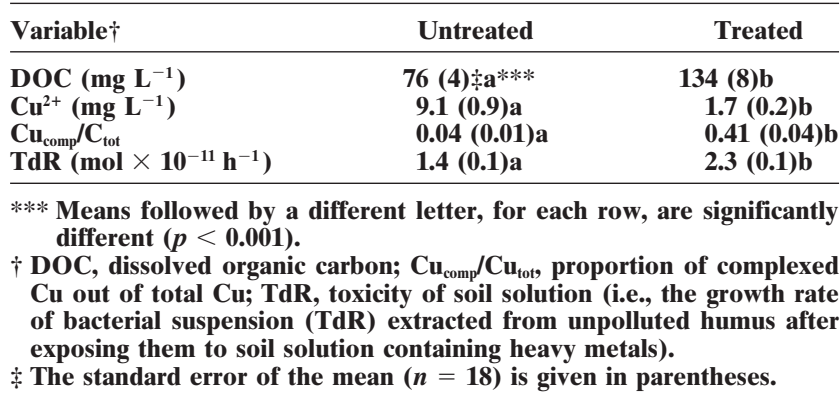




\section{Microbial Activities}

The microbial activity measured as basal respiration was slightly higher on the $\mathrm{T}$ plots than on the $\mathrm{U}$ plots one summer after addition of the mulch (Table 1). The difference between the treatments subsequently increased, the values at the last sampling being $10.5 \pm 0.4$ and $6.7 \pm 0.3 \mu \mathrm{g} \mathrm{CO}_{2} \mathrm{~g} \mathrm{~h}^{-1}$, respectively. Litter decomposition was faster on the $\mathrm{T}$ plots after three growing seasons, the loss in weight of the needles on the $\mathrm{T}$ plots being $50.9 \pm 0.3 \%$ and on the $U$ plots $46.5 \pm 0.3 \%$. The bacterial growth rate, the number of cells, and the specific growth rate per bacterial cell were higher on the $\mathrm{T}$ plots on each sampling occasion that they were measured. There was a slight difference between the treatments with respect to bacterial copper tolerance after $1 \mathrm{yr}$. The tolerance on the T plots decreased subsequently, the $\mathrm{IC}_{50}$ values at the last sampling being $-2.6 \pm$ 0.1 and $-1.7 \pm 0.1 \log M \mathrm{Cu}$ for the $\mathrm{T}$ and $\mathrm{U}$ plots, respectively. The indicators of bacterial and fungal biomass determined on the basis of the PLFA analysis were not affected by the treatments.

\section{Canonical Correlation Analysis}

The canonical correlation analysis (CCA) of the chemical and biological variables for the last sampling is presented in Fig. 1. The exchangeable Ni concentration had no effect on the CCA, and was excluded from the CCA for the last sampling. Copper in ionic form $\left(\mathrm{Cu}^{2+}\right)$ was selected to represent the pollution in CCA.

The canonical structure, providing the correlations of the original variables with their first canonical variables, and the proportion of explained variances, are presented in Table 3 for the last sampling date. The first canonical variable (CHEM), formed from the chemical data set, explained $48 \%$ of the total variance in the chemical data set, suggesting that the first canonical variable provided a fairly effective summary of the original chemical variables. The first biological canonical variable (BIOL)

Table 3. Summary of the canonical correlation analysis in autumn 1998.

\begin{tabular}{|c|c|c|c|}
\hline Chemical variable $\dagger$ & CHEM & Biological variable $\dagger$ & BIOL \\
\hline pH & $0.97+$ & BR & 0.91 \\
\hline $\mathrm{Cu}^{2+}$ & -0.91 & TdR & 0.89 \\
\hline DM & -0.17 & ML & 0.78 \\
\hline \multirow[t]{7}{*}{ OM } & -0.01 & AO & 0.58 \\
\hline & & $\mathbf{I C}_{50}$ & -0.85 \\
\hline & & TdR/AO & 0.26 \\
\hline & & PLFA $_{\text {tot }}$ & -0.14 \\
\hline & & $\mathbf{P L F A}_{\text {bact }}$ & -0.17 \\
\hline & & $\mathbf{P L F A}_{\text {fung }}$ & -0.23 \\
\hline & & $\mathbf{P L F A}_{\text {bact }} / \mathbf{P L F A}_{\text {fung }}$ & -0.15 \\
\hline$\% \mathbf{C} \S$ & 48 & $\% \mathbf{B}$ & 33 \\
\hline$\% \mathbf{B}$ & 45 & & \\
\hline
\end{tabular}

$\dagger$ DM, soil dry weight; OM, organic matter content; BR, microbial respiration activity; TdR, bacterial growth rate; $\mathrm{IC}_{50}$, bacterial copper tolerance; AO, number of bacterial cells; TdR/AO, specific bacterial growth rate; PLFA $_{\text {to }}$, total microbial biomass; PLFA, bact , bacterial biomass; PLFA fung, $_{\text {f }}$ fungal biomass; PLFA $_{\text {fung }} /$ PLFA $_{\text {bact }}$, ratio of fungal to bacterial biomass; ML, litter decomposition (i.e., percent of litter weight loss).

$¥$ The correlations between the original and the first canonical variables CHEM (chemical data set) and BIOL (biological data set).

$\S \% \mathrm{C}$, standardized variance of the chemical variables explained by $\mathrm{CHEM}$ $\% \mathrm{~B}$, standardized variance of the biological variables explained by CHEM and BIOL. explained less $(33 \%)$ of the total variation in the biological data set. The correlation between the first canonical variables CHEM and BIOL (canonical correlation) was $0.97(p<0.0001)$.

The interpretation of CCA with respect to the treatments is presented in Fig. 1, where the sample plots are plotted along the first canonical axes CHEM and BIOL, the arrows describing the canonical structure (Table 3 ). The T sample plots are mostly situated in the right upper corner and, according to the canonical structure, are characterized by a high $\mathrm{pH}$ and low $\mathrm{Cu}^{2+}$ concentration and high microbial activity, high bacterial growth rate, and low bacterial copper tolerance. A lower $\mathrm{pH}$, higher $\mathrm{Cu}^{2+}$ concentration and lower microbial activity and higher bacterial copper tolerance characterize the $\mathrm{U}$ plots.

As all the biological variables were not determined on the other sampling dates, the CCA results (not shown) are not comparable and the time trend cannot be precisely interpreted. However, the main results of the CCAs were rather similar from the second sampling onward. The separation of the treatments was clearly visible from the second sampling onward. From the second to the fifth sampling time the canonical variables CHEM and BIOL differed significantly $(p<0.001)$ between the treatments in ANOVA. The $r^{2}$ values for CHEM were $0.53,0.82,0.43$, and 0.82 for the second, third, fourth, and fifth sampling time, respectively. The respective $r^{2}$ values for BIOL were $0.58,0.82,0.35$, and 0.78 .

\section{Structure of the Microbial Community}

The PLFA pattern was subjected to the multidimensional scaling procedure. A two-dimensional solution was selected for MDS ordination (autopilot mode in program PC-ORD), the minimum stress value obtained being 0.14 . The PLFA pattern differed between the sampling dates, but not between the treatments (Fig. 2 ). This was further confirmed by the results of the vector fitting procedure. None of the environmental variables had significant correlation with the ordination (vectors not shown), indicating that chemical variables, which separated the treatments in CCA (i.e., the $\mathrm{Cu}_{\mathrm{exc}}$ concentration and $\mathrm{pH}$ ) did not correlate with the sample plot ordination. The variables that varied between the sampling dates (i.e., DM and OM) did not show any correlation with the ordination. However, when the T and $\mathrm{U}$ plots of the last sampling date were plotted (Fig. 3 ), the treatments were slightly separated. Overall, however, the differences in the PLFA patterns were very small (Table 4).

\section{DISCUSSION}

The aim of this bioremediation experiment was to diminish the toxicity of heavy metal-polluted soil to the microbiota. According to the results of the $\left[{ }^{3} \mathrm{H}\right]-$ thymidine incorporation analysis, the toxicity of the soil solution to bacteria decreased on the treated plots. The decrease in toxicity is due to the conversion of toxic metal ions into less bioavailable forms (e.g., by precipita- 
Table 4. Amounts of phospholipid fatty acids (PLFAs) in organic soil three growing seasons after the remediation treatment.

\begin{tabular}{|c|c|c|}
\hline PLFA & Untreated & Treated \\
\hline \multicolumn{3}{|l|}{$\mathrm{mol} \%$} \\
\hline i14:0 & $0.33(0.01) \dagger$ & $0.38(0.01)$ \\
\hline 14:0 & $2.52(0.06)$ & $2.49(0.07)$ \\
\hline i15:0 & $12.18(0.19)$ & $11.50(0.18)$ \\
\hline a15:0 & $3.22(0.07)$ & $3.46(0.07)$ \\
\hline C15:1 & $1.01(0.07)$ & $0.95(0.07)$ \\
\hline $15: 0$ & $0.87(0.01)$ & $0.91(0.02)$ \\
\hline i16:1 & $1.00(0.06)$ & $1.04(0.07)$ \\
\hline i16:0 & $5.00(0.11)$ & $5.05(0.10)$ \\
\hline $16: 1 \omega 9$ & $0.68(0.02)$ & $0.74(0.02)$ \\
\hline $16: 1 \omega 7 \mathrm{c}$ & $5.11(0.07)$ & $5.04(0.08)$ \\
\hline $16: 1 \omega 7 t$ & $0.84(0.02)$ & $0.79(0.02)$ \\
\hline $16: 1 \omega 5$ & $2.08(0.05)$ & $2.27(0.05)$ \\
\hline 16:0 & $16.80(0.36)$ & $17.19(0.29)$ \\
\hline br17:0 & $0.36(0.01)$ & $0.37(0.01)$ \\
\hline 10Me16:0 & $8.16(0.26)$ & $8.23(0.19)$ \\
\hline i17:0 & $2.10(0.05)$ & $2.06(0.06)$ \\
\hline a17:0 & $1.43(0.03)$ & $1.50(0.02)$ \\
\hline $17: 1 \omega 8$ & $0.57(0.01)$ & $0.55(0.01)$ \\
\hline cy17:0 & $2.18(0.04)$ & $2.19(0.03)$ \\
\hline $17: 0$ & $0.72(0.01)$ & $0.74(0.01)$ \\
\hline br18:0 & $1.58(0.06)$ & $1.56(0.08)$ \\
\hline 10Me17:0 & $1.07(0.05)$ & $1.11(0.04)$ \\
\hline $18: 2 \omega 6,9$ & $1.98(0.12)$ & $2.12(0.09)$ \\
\hline 18:169 & $5.70(0.10)$ & $5.83(0.11)$ \\
\hline 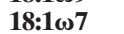 & $3.12(0.07)$ & 3.38 (0.05) \\
\hline 18:1 & $1.01(0.10)$ & $1.02(0.08)$ \\
\hline 18:0 & 4.09 (0.11) & $4.31(0.11)$ \\
\hline 19:1a & $0.34(0.01)$ & $0.41(0.01)$ \\
\hline 10Me18:0 & $0.98(0.06)$ & $0.91(0.05)$ \\
\hline 19:1b & $2.08(0.10)$ & $2.06(0.09)$ \\
\hline cy19:0 & $6.95(0.11)$ & $6.43(0.11)$ \\
\hline $20: 5$ & 0.88 (0.04) & $0.84(0.04$ \\
\hline 20:4 & $0.12(0.01)$ & $0.18(0.01)$ \\
\hline 20:0 & $2.32(0.08)$ & $2.37(0.10)$ \\
\hline
\end{tabular}

$\uparrow$ The standard error of the mean $(n=18)$ is given in parentheses.

tion as the soil $\mathrm{pH}$ increases) (Alloway, 1995). The addition of mulch resulted in a one $\mathrm{pH}$-unit increase in the organic layer in this experiment. The concentration of exchangeable Ni remained the same, while that of exchangeable $\mathrm{Cu}$ decreased by $30 \%$. This result is in accordance with the findings of earlier studies. The concentration of exchangeable $\mathrm{Cu}$ was found to decrease more than that of exchangeable $\mathrm{Ni}$ after organic substances were added to soil (Ross, 1996). At the same polluted site as that used in this study, Derome and Nieminen (1998) reported $\mathrm{Ni}$ to be readily leached and $\mathrm{Cu}$ to be strongly retained in the organic layer.

Another important process affecting the bioavailability of metals in soils, in addition to a change in soil $\mathrm{pH}$, is complexation between metals and organic substances (Alloway, 1995). Compost addition has resulted in a reduction in the phytotoxicity of soil (Vangronsveld et al., 1995b; Li et al., 2000) but, to our knowledge, metal speciation has not been investigated in field remediation studies. However, speciation has been studied after sewage sludge application. The $\mathrm{Ni}$ and $\mathrm{Zn}$ applied in sludge remained in chemical forms that were available for plant uptake, but the major portion of the $\mathrm{Cu}$ was partitioned into the relatively resistant organic fraction, which probably exhibits low bioavailability (Sloan et al., 1997). In compost most of the $\mathrm{Cu}$ is found in the organic fraction. The complexing capacity of compost was demonstrated by Giusquiani et al. (1992), who found that $\mathrm{Cu}$ and to a lesser extent $\mathrm{Ni}$ complexed with dissolved organic matter. Most of the $\mathrm{Cu}(77 \%)$ and one third of the $\mathrm{Ni}$ in compost occurred in the organic fraction, while the leachable fraction of $\mathrm{Cu}$ was less than $10 \%$ (Tisdell and Breslin, 1995). We found that the mulch application resulted in an increase in DOC in the soil solution, as well as in $\mathrm{Cu}$ complexation, and a corresponding decrease in exchangeable $\mathrm{Cu}$ in the soil. Thus we conclude that soluble and particulate organic matter in the compost had complexed $\mathrm{Cu}$ into less bioavailable forms.

The decreasing $\mathrm{Cu}$ concentration in our field remediation experiment had reduced bacterial tolerance to $\mathrm{Cu}$ after two growing seasons. In laboratory conditions, bacterial tolerance to copper developed rapidly after the $\mathrm{Cu}$ concentration in the soil had increased (Díaz-Raviña and Bååth, 1996). However, the effect of a decreasing $\mathrm{Cu}$ concentration on the heavy metal tolerance of bacteria has not been studied very much. Kelly and Tate (1998), who studied bacterial tolerance to $\mathrm{Zn}$ by the plate count method, found that $\mathrm{Zn}$-tolerant bacteria were not affected by decreasing soluble $\mathrm{Zn}$ concentrations.

Tolerance and adaptation of microorganisms to heavy metals are common phenomena. The increased abundance of tolerant organisms in a polluted environment can be due to genetic changes, to physiological adaptations involving no alterations to the genotype, or to the replacement of metal-sensitive species with species that are already tolerant to heavy metals (Bååth, 1989). A change in species composition has been proposed as the main reason for the change in metal tolerance of microbial populations in laboratory studies (Díaz-Raviña et al., 1994; Frostegård et al., 1993b), and in a field study carried out by Pennanen et al. (1996). In these studies, the heavy metal tolerance of the bacterial community, determined by $\left[{ }^{3} \mathrm{H}\right]$-thymidine incorporation, was accompanied by a change in the microbial community structure, as determined by the PLFA technique. In the present study the microbial community structure showed no changes after $2 \mathrm{yr}$, and only slight changes after 3 yr. Despite this, the copper tolerance of the bacterial community decreased after $2 \mathrm{yr}$ of exposure to the mulch. The PLFA pattern would have changed if the microbes from the mulch had become dominant in the polluted organic layer. Therefore, the results support the alternative hypotheses of genetic change or physiological adaptation of the $\mathrm{Cu}$ tolerant bacteria to diminishing toxic concentrations of heavy metals.

Recovery of the microbiota would occur if the structure of the microbial community gradually became similar to that on unpolluted sites. The PLFA patterns for the less-polluted areas at Harjavalta, studied by Pennanen et al. (1996), and for the mulched plots at our study site, showed some rather similar trends. The relative quantities of the eucaryotic (Amano et al., 1992) PLFAs,

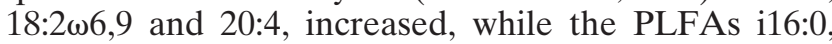
br17:0, and br18:0, common in gram-positive bacteria (O'Leary and Wilkinson, 1988), decreased with decreasing $\mathrm{Cu}$ concentrations along the heavy-metal pollution gradient at Harjavalta. On the treated plots in our reme-

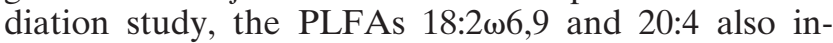
creased when the $\mathrm{Cu}$ concentration decreased. However, most of the PLFAs did not change as a result of the remediation treatment. Fritze et al. (1997) also 
studied the impact of liming at Harjavalta on polluted soil. The PLFAs 16:1 $\omega 5$ and 20:4 increased and i15:0, 16:1 $\omega 7 \mathrm{t}$, br18:0, and cy19:0 decreased on the limed plots, as was the case on the plots covered with mulch in this study. However, the differences in the relative abundance of PLFAs in our remediation study were very small, and therefore these signs of the recovery of the microbial community are only tentative.

A change in the microbial community was found in the remediation study of Kelly and Tate (1998), who investigated the microbial community using the BIOLOG procedure. The metabolic profiles of the sites treated with sewage sludge were clustered close to the least-contaminated sites, indicating a change in the microbial community toward unpolluted sites. However, they found no change in bacterial metal tolerance using the plate count method. In our study, the microbial community did not appear to change rapidly toward the structure of an unpolluted community, but instead the community that was adapted to heavy metals seemed to lose its heavy metal tolerance when the metal concentrations decreased.

Some similar features were found between the effects of the remediation experiment, in which the $\mathrm{pH}$ increased by about one unit, and forest liming. The total microbial biomass remained unchanged after liming (Frostegård et al., 1993a) and after the remediation treatment in this study. Liming has frequently been reported to increase microbial activity (Zelles et al., 1987; Persson et al., 1989; Illmer and Schinner, 1991) and the bacterial growth rate (Bååth and Arnebrandt, 1994), as was the case in this study. Forest liming (Frostegård et al., 1993a) and ash application (Bååth et al., 1995) alter the microbial community structure toward one more dominated by gram-negative bacteria. These authors found an increase in the PLFAs i14:0, 16:1 $\omega 5,16: 1 \omega 9$, 18:1 $1 \omega 7$, and 19:1a, and a decrease in, for example, the PLFAs i15:0 and cy:19, as a result of limestone or ash application. Similar slight changes were also found on the mulched plots in our remediation study. However, nine PLFAs, which Frostegård et al. (1993a) and Bååth et al. (1995) reported to correlate with $\mathrm{pH}$, showed an opposite change or none at all in this remediation study. Bååth et al. (1995) discussed the reason for the altered PLFA pattern after the increase in $\mathrm{pH}$. They concluded that it was not $\mathrm{pH}$ as such that was the reason for the altered PLFA pattern, but rather the change in substrate quality and quantity (i.e., in the available soil organic matter). The amount of dissolved organic carbon increased on the treated plots in our study, indicating an increase in such substrates.

In conclusion, application of mulch to a heavy metalpolluted soil decreased the toxicity of the soil solution to bacteria. The decreased toxicity was reflected in the organic layer as increased microbial activity and bacterial growth rate, and as decreased tolerance of the bacteria to heavy metals. The variables that did not change or changed only slightly were the exchangeable Ni concentration in the soil, and the microbial biomass and the structure of the microbial community. The positive changes indicate remediation of the polluted soil. How- ever, the mulch, which consisted of compost and woodchips, has not yet decomposed completely, and final conclusions about remediation cannot be drawn until a number of years have passed. Further research could focus on the addition of chemical agents to the mulch in order to further increase $\mathrm{Cu}$ immobilization, as well as that of $\mathrm{Ni}$ and other metals.

\section{ACKNOWLEDGMENTS}

We are grateful to Anneli Rautiainen, Päivi Tikka, and Thomas Brügger for their help in the laboratory work, Christian Uhlig for the field work, and Anne Siika for help with the illustrations. We thank the Isotope Laboratory of the University of Helsinki for the use of a scintillation counter. We thank Heljä-Sisko Helmisaari for fruitful cooperation within the "Recovery of a Boreal Forest Ecosystem from Long-Term Heavy-Metal Pollution" project. The work was funded by the Academy of Finland and the Maj and Tor Nessling Foundation.

\section{REFERENCES}

Alloway, B.J. 1995. Soil processes and the behaviour of metals. p 11-37. In B.J. Alloway (ed.) Heavy metals in soils. Blackie Academic \& Professional, London, UK

Amano, N., Y. Shinmen, K. Akimoto, H. Kawashima, and T. Amichi. 1992. Chemotaxonomic significance of fatty acid composition in the genus Mortierella (Zygomycetes, Mortierellaceae). Mycotaxonomy 44:257-265.

Anonymous. 1988. Soil map of the world. World Soil Resour. Rep. 60:1-115. Food and Agriculture Organization of the United Nations, Rome, Italy.

Anonymous. 1991. Wallac 1409/1411. DSA-based liquid scintillation counters. Instrument manual. Wallac, Turku, Finland.

Bååth, E. 1989. Effects of heavy metals in soil on microbial processes and populations. Water Air Soil Pollut. 47:335-379.

Bååth, E. 1992a. Thymidine incorporation into macromolecules of bacteria extracted from soil by homogenization-centrifugation. Soil Biol. Biochem. 24:1157-1165.

Bååth, E. 1992b. Measurement of heavy metal tolerance of soil bacteria using thymidine incorporation into bacteria extracted after homogenization-centrifugation. Soil Biol. Biochem. 24:1167-1172.

Bååth, E., and K. Arnebrant. 1994. Growth rate and response of bacterial communities to $\mathrm{pH}$ in limed and ash treated forest soils. Soil Biol. Biochem. 26:995-1001.

Bååth, E., A. Frostegård, T. Pennanen, and H. Fritze. 1995. Microbial community structure and $\mathrm{pH}$ response in relation to soil organic matter quality in wood-ash fertilized, clear-cut or burned coniferous forest soils. Soil Biol. Biochem. 27:229-240.

Baker, D.E., and J.P. Senft. 1995. Copper. p. 179-205. In B.J. Alloway (ed.) Heavy metals in soils. Blackie Academic \& Professional, London, UK

Berggren, D. 1989. Speciation of aluminium, cadmium, copper and lead in humic soil solutions-A comparison of the ion exchange column procedure and equilibrium dialysis. Int. J. Environ. Anal Chem. 35:1-15.

Cajander, A.K. 1949. Forest types and their significance. Acta For. Fenn. 56:1-71.

Chefetz, B., P.G. Hatcher, Y. Hadar, and Y. Chen. 1996. Chemical and biological characterization of organic matter during composting of municipal solid waste. J. Environ. Qual. 25:776-785.

Chen, X., J.V. Wright, J.L. Conca, and L.M. Peurrung. 1997. Evaluation of heavy metal remediation using mineral apatite. Water Air Soil Pollut. 98:57-78.

Clarke, K.R. 1999. Nonmetric multivariate analysis in communitylevel ecotoxicology. Environ. Toxicol. Chem. 18:118-127.

Czupyrna, G., R.D. Levy, A.I. MacLean, and H. Gold. 1989. In situ immobilization of contaminated soils. Noyes Data Corporation, Park Ridge, NJ.

Derome, J., and A. Lindroos. 1998. Effects of heavy metal contamination on macronutrient availability and acidification parameters in forest soil in the vicinity of the Harjavalta $\mathrm{Cu}-\mathrm{Ni}$ smelter, SW Finland. Environ. Pollut. 99:225-232. 
Derome, J., and T. Nieminen. 1998. Metal and macronutrient fluxes in heavy-metal polluted Scots pine ecosystems in SW Finland. Environ. Pollut. 103:219-228.

Díaz-Raviña, M., and E. Bååth. 1996. Development of metal tolerance in soil bacterial communities exposed to experimentally increased metal levels. Appl. Environ. Microbiol. 62:2970-2977.

Díaz-Raviña, M., E. Bååth, and Å. Frostegård. 1994. Multiple heavy metal tolerance of soil bacterial communities and its measurement by a thymidine incorporation technique. Appl. Environ. Microbiol. 60:2238-2247.

Dick, W.A., and E.L. McCoy. 1993. Enhancing soil fertility by addition of compost. p. 622-644. In H.A.J. Hoitink and H.M. Keener (ed.) Science and engineering of composting: Design, environmental, microbiological and utilization aspects. The Ohio State Univ., Renaissance Publ., Worthington, $\mathrm{OH}$.

Faith, D.P., P.R. Minchin, and L. Belbin. 1987. Compositional dissimilarity as a robust measure of ecological distance. Vegetatio 69:57-68.

Federle, T.W. 1986. Microbial distribution in soil-New techniques. p. 493-498. In F. Megusar and M. Gantar (ed.) Perspectives in microbial ecology. Slovene Society for Microbiology, Ljubjana, Slovenia.

Fisher, K., H.P. Bipp, P. Riemschneider, P. Leidmann, D. Bieniek, and A. Kettrup. 1998. Utilization of biomass residues for the remediation of metal-polluted soils. Environ. Sci. Technol. 32:2154-2161.

Fritze, H., S. Niini, K. Mikkola, and A. Mäkinen. 1989. Soil microbial effects of a $\mathrm{Cu}-\mathrm{Ni}$ smelter in southwestern Finland. Biol. Fertil. Soils 8:87-94.

Fritze, H., T. Pennanen, and P. Vanhala. 1997. Impact of fertilizers on the humus layer microbial community of Scots pine stands growing along a gradient of heavy metal pollution. p. 69-83. In $\mathrm{H}$. Insam and A. Rangger (ed.) Microbial communities: Functional versus structural approaches. Springer-Verlag, Berlin, Germany.

Fritze, H., J. Perkiömäki, U. Saarela, R. Katainen, P. Tikka, K. Yrjälä, M. Karp, J. Haimi, and M. Romantschuk. 2000. Effect of Cdcontaining wood ash on the microflora of coniferous forest humus FEMS Microbiol. Ecol. 32:43-51.

Frostegård, Å., and E. Bååth. 1996. The use of phospholipid fatty acid analysis to estimate bacterial and fungal biomass in soil. Biol. Fertil. Soils. 22:59-65.

Frostegård, Å., E. Bååth, and A. Tunlid. 1993a. Shifts in the structure of soil microbial communities in limed forests as revealed by phospholipid fatty acid analysis. Soil Biol. Biochem. 25:723-730.

Frostegård, Å., A. Tunlid, and E. Bååth. 1993b. Phospholipid fatty acid composition, biomass, and activity of microbial communities from two soil types experimentally exposed to different heavy metals. Appl. Environ. Microbiol. 59:3605-3617.

García-Sánchez, A., A. Alastuey, and X. Querol. 1999. Heavy metal adsorbtion by different minerals: Application to the remediation of polluted soils. Sci. Total Environ. 242:179-188.

Geisler, R. 1996. Chemistry of soil solution extracted by centrifugation-Methodology and field applications. Doctoral thesis. Swedish Univ. of Agric. Sci., Dep. of Forest Ecology, Umeå, Sweden.

Gittins, R. 1985. Canonical analysis: A review with applications in ecology. Biomathematics Vol. 12. Springer-Verlag, Berlin, Germany.

Giusquiani, P.L., G. Gigliotti, and D. Businelli. 1992. Mobility of heavy metals in urban waste-amended soils. J. Environ. Qual. 21:330-335.

Gworek, B. 1992. Inactivation of cadmium in contaminated soils using synthetic zeolites. Environ. Pollut. 75:269-271.

Helmisaari, H.-S., K. Makkonen, M. Olsson, A. Viksna, and E. Mälkönen. 1999. Fine-root growth, mortality and heavy metal concentrations in limed and fertilized Pinus silvestris (L.) stands in the vicinity of a Cu-Ni smelter in SW Finland. Plant Soil 209:193-200.

Illmer, P., and F. Schinner. 1991. Effect of lime and nutrients salts on the microbiological activities of forest soils. Biol. Fertil. Soils 11:261-266

Kelly, J.J., and R.L. Tate. 1998. Effects of heavy metal contamination and remediation on soil microbial communities in the vicinity of a zinc smelter. J. Environ. Qual. 27:609-617.

Kiikkilä, O., T. Pennanen, J. Pietikäinen, K.-R. Hurme, and H. Fritze. 2000. Some observations on the copper tolerance of bacterial communities determined by the $\left[{ }^{3} \mathrm{H}\right]$-thymidine incorporation method in heavy metal polluted humus. Soil Biol. Biochem. 32:883-885.

Krebs, R., S.K. Gupta, G. Furrer, and R. Schulin. 1999. Gravel sludge as an immobilizing agent in soils contaminated by heavy metals: A field study. Water Air Soil Pollut. 115:465-479.
Li, Y.-M., R.L. Chaney, G. Siebielec, and B.A. Kerschner. 2000. Response of four turfgrass cultivars to limestone and biosolids-compost amendment of a zinc and cadmium contaminated soil at Palmerton, Pennsylvania. J. Environ. Qual. 29:1440-1447.

Mäkelä-Kurtto, R., and J. Sippola. 1995. Erilliskerätyn biojätekompostin lannoitusvaikutus. [In Finnish.] Pääkaupunkiseudun julkaisusarja C:18. YTV, Helsinki, Finland.

Mäkelä-Kurtto, R., and J. Sippola. 1996. Kasvu-Yty komposti vihannesviljelyssä. [In Finnish.] Pääkaupunkiseudun julkaisusarja C:5. YTV, Helsinki, Finland

Mälkönen, E., J. Derome, H. Fritze, H.-S. Helmisaari, M. Kukkola, M. Kytö, A. Saarsalmi, and M. Salemaa. 1999. Compensatory fertilization of Scots pine stands polluted by heavy metals. Nutr. Cycl. Agroecosyst. 55:239-268.

McCune, B., and M.J. Mefford. 1999. PC-ORD. Multivariate analysis of ecological data. Version 4. MjM Software Design, Gleneden Beach, OR.

Mench, M., J. Vangronsveld, V. Didier, and H. Clijsters. 1994. Evaluation of metal mobility, plant availability and immobilization by chemical agents in a limed-silty soil. Environ. Pollut. 86:279-286.

Minchin, P.R. 1987. An evaluation of the relative robustness of techniques for ecological ordination. Vegetatio 69:89-107.

O'Leary, W.M., and S.G. Wilkinson. 1988. Gram-positive bacteria. p. 117-202. In C. Ratledge and S.G. Wilkinson (ed.) Microbial lipids. Vol. 1. Academic Press, London, UK.

Pennanen, T., Å. Frostegård, H. Fritze, and E. Bååth. 1996. Phospholipid fatty acid composition and heavy metal tolerance of soil microbial communities along two heavy metal-polluted gradients in coniferous forests. Appl. Environ. Microbiol. 62:420-428.

Pennanen, T., J. Liski, E. Bååth, V. Kitunen, J. Uotila, C.J. Westman, and H. Fritze. 1999. Structure of the microbial communities in coniferous forest soils in relation to site fertility and stand development stage. Microbiol. Ecol. 38:168-179.

Persson, T., H. Lundkvist, A. Wiren, R. Hyvönen, and B. Wessen. 1989. Effects of acidification and liming on carbon and nitrogen mineralisation and soil organisms in mor humus. Water Air Soil Pollut. 45:77-96.

Pietikäinen, J., and H. Fritze. 1995. Clear-cutting and prescribed burning in coniferous forest: Comparison of effects on soil fungal and total microbial biomass, respiration activity and nitrification. Soil Biol. Biochem. 27:101-109.

Pollard, P.C., and J.W. Moriarty. 1984. Validity of the tritiated thymidine method for estimating bacterial growth rates: Measurement of isotope dilution during DNA synthesis. Appl. Environ. Microbiol. 48:1076-1083.

Ross, S.M. 1996. Retention, transformation and mobility of toxic metals in soils. p. 63-151. In S.M. Ross (ed.) Toxic metals in soil-plant systems. John Wiley \& Sons, Chichester, UK.

Sabey, B.R., R.L. Pendleton, and B.L. Webb. 1990. Effect of municipal sewage sludge application on growth of two reclamation shrub species in copper mine spoils. J. Environ. Qual. 19:580-586.

Salemaa, M., I. Vanha-Majamaa, and J. Derome. 2001. Understorey vegetation along a heavy-metal pollution gradient in SW Finland. Environ. Pollut. 112:339-350.

Salt, D.E., R.D. Smith, and I. Raskin. 1998. Phytoremediation. Annu. Rev. Plant Physiol. Plant Mol. Biol. 49:643-668.

SAS Institute. 1996. Version 6.12 for Windows. SAS Inst., Cary, NC

Sloan, J.J., R.H. Dowdy, M.S. Dolan, and D.R. Linden. 1997. Longterm effects of biosolids applications on heavy metal bioavailability in agricultural soils. J. Environ. Qual. 26:966-974.

Tisdell, S.E., and V.T. Breslin. 1995. Characterization and leaching of elements from municipal solid waste compost. J. Environ. Qual. $28: 827-833$.

Vangronsveld, J., and H. Clijsters. 1992. A biological test system for the evaluation of metal phytotoxicity and immobilization by additives in metal contaminated soils. 117-125. In E. Merian and W. Haerdi (ed.) Metal compounds in environment and life. 4. Science and Technol. Lett., Northwood, UK.

Vangronsveld, J., J.V. Colpaert, and K.K. Van Tichelen. 1996. Reclamation of a bare industrial area contaminated by non-ferrous metals: Physico-chemical and biological evaluation of the durability of soil treatment and revegetation. Environ. Pollut. 94:131-140.

Vangronsveld, J., J. Sterckx, F. Van Assche, and H. Clijsters. 1995a. Rehabilitation studies on an old non-ferrous waste dumping ground: 
Effects on revegetation and metal immobilization by beringite. J. Geochem. Expl. 52:221-229.

Vangronsveld, J., F. Van Assche, and H. Clijsters. 1995b. Reclamation of a bare industrial area contaminated by non-ferrous metals: In situ metal immobilization and revegetation. Environ. Pollut. 87:51-59.
Van den Wollenberg, A.L. 1977. Redundancy analysis: An alternative for canonical correlation analysis. Psychometrica 42:207-219.

Zelles, L., I. Scheunert, and K. Kreutzer. 1987. Effect of artificial irrigation, acid precipitation and liming on the microbial activity in soil of a spruce forest. Biol. Fertil. Soils 4:137-143.

\title{
Ecological Risk Assessment
}

\section{Factors Affecting the Ratio of Cation Exchange Capacity to Clay Content in Lignite Overburden}

\author{
W. M. Stewart and L. R. Hossner*
}

\begin{abstract}
Unusually high cation exchange capacity (CEC) values relative to clay content are frequently reported for lignite overburden and minesoils. The CEC to percent clay ratio is commonly greater than one and would require that the average charge of the clay fraction be greater than $100 \mathrm{cmol}_{\mathrm{c}} \mathrm{kg}^{-1}$. A comparison of methods for particlesize distribution suggests that the major reason lignite overburden samples have CEC to percent clay ratios greater than one is incomplete dispersion of aggregates of clay minerals or shale fragments. Preliminary investigations revealed the presence of shale fragments, smectite, and partially weathered mica in the silt fraction. Methods commonly used in soil textural analysis underestimated clay content by approximately $24 \%$. The silt fraction may, therefore, provide a "hidden" source of CEC. Another important factor influencing the CEC to percent clay ratio was the presence of organic materials (lignite) in the samples. Lignite may make a significant contribution to CEC in overburden materials. In a study designed to estimate the $\mathrm{pH}$ dependent charge of both the mineral and organic fractions, the CEC of overburden organic constituents was determined to be approximately $158 \mathrm{cmol}_{\mathrm{c}} \mathrm{kg}^{-1}$ at $\mathrm{pH} \mathrm{8.2}$. The high CEC to percent clay ratio in lignite overburden and minesoils may be resolved by adjusting methods for clay determination to optimize dispersion and by accounting for CEC due to organic materials. An alternative approach is to use existing methodology and use correction factors to account for incomplete dispersion of clay minerals and the charge contributions of organic materials.
\end{abstract}

$\mathrm{T}$ HE Railroad Commission of Texas uses the CEC to percent clay ratio of minesoils and overburden samples as one measure of the adequacy of laboratory data submitted by the mining companies. Cation exchange capacity to percent clay ratios greater than one are frequently reported for overburden and minesoils in the Gulf Coast lignite region. This suggests a clay fraction dominated by minerals with CEC greater than $100 \mathrm{cmol}_{\mathrm{c}} \mathrm{kg}^{-1}$ (vermiculite and/or high charge smectite), excessive levels of organic materials (lignite), or errors in the method of CEC, percent clay, or organic carbon determination.

The mineralogy of overburden and native soils overlying Texas lignite has been investigated and described

Department of Soil and Crop Sciences, Texas A\&M University, College Station, TX 77843. Received 21 Apr. 2000. *Corresponding author (1-hossner@tamu.edu).

Published in J. Environ. Qual. 30:1143-1149 (2001). by several researchers (Askenasy, 1977; Dixon et al., 1980; Senkayi et al., 1983; Arora et al., 1984). The most commonly occurring clay minerals in fluvial overburden sediments are smectite, kaolinite, mica, vermiculite, and chlorite (Dixon et al., 1980; Senkayi et al., 1983; Arora et al., 1984). Distribution of these minerals varies widely with depth and location.

Smectite is an important mineral in Wilcox Group overburden. Arora et al. (1984) found smectite to be the predominant clay mineral in the fine clay fraction of most east Texas lignite overburden samples with amounts ranging from 21 to $46 \%$. High charge smectite has been identified in these overburden materials (Egashira et al., 1982; Senkayi et al., 1985). These researchers suggest that this mineral may be the result of mica weathering. High charge smectite has charge properties intermediate between those of smectite and vermiculite with a layer charge near that of vermiculite. Kaolinite is the most abundant mineral in the coarse clay $(2-0.2 \mu \mathrm{m})$ size fraction and the second most abundant, after smectite, in the fine clay fraction of Wilcox Group overburden (Arora et al., 1984). Mica is common in the clay fraction of these overburden materials. Mica is generally present in lower quantities than either smectite or kaolinite (Dixon et al., 1982). Chlorite has been identified in the $<2.0-\mu \mathrm{m}$ clay fraction of Texas lignite overburden (Askenasy, 1977; McAllister, 1981; Senkayi et al., 1981, 1983; Arora et al., 1984) and occurs primarily in the reduced overburden zone (Senkayi et al., 1983). The sand and silt fractions of these materials consist primarily of quartz and feldspars with lesser amounts of mica, kaolinite, and smectite (Arora et al., 1984). Other minerals may include gypsum, jarosite, barite, calcite, siderite, magnesite, dolomite, rhodochrocite, and pyritic minerals (Dixon et al., 1982). Also siderite may weather to form goethite, hematite, and todorokite (Senkayi et al., 1986).

Reasonable hypotheses for the rather high CEC to percent clay ratios include incomplete dispersion of aggregates of clay minerals in the determination of clay content, the presence of lignite or other organic material not readily oxidized by the conventional method of or-

Abbreviations: CEC, cation exchange capacity; EDS, energy-dispersive X-ray spectrometer; SEM, scanning electron microscope. 